\title{
Developing Needs Analysis Based-Reading Comprehension Learning Materials: A Study on the Indonesian Language Study Program Students
}

\author{
S. Salam* \\ The Indonesian Language Education and Literary Study Program, Faculty of Literary and Culture, Universitas Negeri Gorontalo, Jalan \\ Jend. Sudirman No. 6 Kota Gorontalo, Indonesia PO box 96128
}

Corresponding Author: S. Salam, E-mail: salamtolaki@ung.ac.id

\section{ARTICLE INFO}

Article history

Received: June 09, 2017

Accepted: August 06, 2017

Published: August 31, 2017

Volume: 8 Issue: 4

Advance access: August 2017

Conflicts of interest: None

Funding: None

Key words:

Development of Teaching Materials,

Needs Analysis,

Teaching Material Analysis

ABSTRACT

The purpose of this research was to describe the need of development of 'Reading Comprehension' teaching materials to students and lecturers of Indonesian Language and Literature Education Department, Gorontalo. This research is included in the research and development to develop educational products in the form of teaching materials. Mixed research design was used in this study to explore the data needs of the development of reading materials learning. Quantitative data was obtained from the responses of 36 respondents and 2 lecturers of the Reading subjects on the questionnaire needs analysis and questionnaire of teaching material analysis that is being used today. Likert Scale was used in questionnaire of needs analysis seen from 7 aspects, namely: content of teaching material, reading strategy, text type, text genre, text topic, learning activity, and evaluation of learning (81 items) and questionnaire of teaching material analysis that was being used that amounted to 5 aspects, namely: the content of teaching materials, organization of teaching materials, language, layout, and completeness of teaching material support (31 items). Qualitative data were obtained from open questions about the experiences of students and lecturers in reading learning in the same questionnaire, as well as content analysis of the material being used. The results showed that the requirement of development of teaching materials, students and lecturers assessed 63 items (77.78\%) in the required category, and 18 items $(22.22 \%)$ with the required categories. Then, the teaching materials currently in use still lack the aspects of the content, the text type, the text genre, the text topic, and the evaluation of each learning unit. Details of the results obtained 4 items (12.90\%) as low category, 22 items $(70.97 \%)$ as enough category, and 5 items $(16.13 \%)$ as high category.
\end{abstract}

\section{INTRODUCTION}

Learning the skills of reading as a college subject must be supported by the availability of teaching materials. Therefore, teaching materials is one of the aspects that helped determine the success of learning, in addition to other aspects of learning such as syllabus, methods, learning activities, and evaluation. Therefore, the lecturers are obliged to write and develop teaching materials to read so that the teaching materials are always up-to-date.

The development of teaching materials is very important because the conditions in the field show that teaching materials that support the learning process of reading courses are still very limited. This condition is happening in the Department of Indonesian Language Education and Literature, Gorontalo. Therefore, there are three considerations for the need to develop reading material. First, the teaching materials used today have not been made any changes or material development for the last 10 years. Second, the use of books and the selection of teaching materials to read not through the proper procedures. Third, the design of syllabus and reading teaching materials that are being used are not in accordance with the Indonesian National Qualification Framework (KKNI). The availability of reading materials helps students greatly in understanding the learning materials and to improve their understanding of each reading material. Grellet (1981: 11) argues that teaching materials build student belief and confidence.

Good teaching materials are teaching materials that can be used and help students in the learning process. To that end, teaching materials should be prepared based on the needs of students and lecturers. The need for teaching learning materials is determined by the environment, the development of information technology, and the culture of the community in which education takes place. This means that different analysis results may be obtained from the same subject to different universities.

In addition to aspects of needs analysis, the development of teaching materials should take into account the results of the analysis of the teaching materials that are being used. The gap between the wishes of students and lecturers with the condition of existing teaching materials becomes a necessity, namely the need for the development of teaching 
materials 'reading comprehension'. For that, there are two problems studied in this research, namely: (1) how is the need of teaching materials reading students and lecturers majoring in Indonesian Language Education and Literature, Universitas Negeri Gorontalo? (2) how is the reading material currently in use in the Department of Indonesian Language and Literature, Faculty of Letters and Culture, Universitas Negeri Gorontalo? Based on the problem, the purpose of this research is to: (1) identify the needs of students and lecturers in the lecture subject to read; and (2) analyzing the teaching materials that are being used in the current reading subject.

\section{THEORETICAL BASIS}

This research is included in the development research to produce a model of reading material. Model according to Verspool, et al. (2011:99-100) is "a representation of the essential aspects of an existing system (or a system to be constructed) that presents the knowledge of that system in usable form". While research and development according to Sugiyono (2015:28) is a process/method used to validate and develop the product. Teaching materials as one of the research and development products are made to meet the learning needs of students or students. This is consistent with Gay, Mills, and Airasian views that " $\mathrm{R} \& \mathrm{D}$ produces quality products designed to meet educational needs.

Writing of teaching materials should be through good planning and mature, so as to produce teaching materials that can help students when learning. This is in line with Graves's (2000:150) view that the development of teaching materials is a planning process by a teacher or lecturer in creating learning units and these learning units carry general and specific objectives of learning. Development of teaching materials means making, selecting, adjusting, and organizing materials and activities so that learners can achieve goals that will help them achieve their learning goals.

The need of students in writing reading material is the first consideration for Graves (2000:156). He put forward several considerations in developing the material, the first is the consideration of the student aspect. In this case, the material should be made relevant to their experience and background, the material must be relevant to their target needs (outside the classroom), and the material should be relevant to their affective needs. The importance of writing teaching materials by considering the aspects of needs, also put forward by Nunan (1996:104) material in accordance with the needs expressed by learners (students). Even Tomlinson $(2007: 108)$ puts the identification of needs in the first order of the seven steps of developing the teaching material model.

Needs analysis is a procedure that must be done by researchers when will produce research and development products. This is as Richards (2001:51) points out that "procedures used to collect information about learners needs are known an needs analysis". According to Hutchinson and Waters (in Nation and Macalister, 2010:24) needs analysis takes into account three aspects: the aspects of necessities, the lack of aspects, and the aspect of needs. Based on the division, the necessities and the lack of included in the knowledge, while the aspect of desire (want) entry as subjective needs.
According to Suparman (2004:73) the need is a gap between the current state compared with the situation that should be. In other words, any state that is less than that should indicate a need.

\section{RESEARCH METHODOLOGY}

This research is a development research so that the data type consists of qualitative and quantitative data. Therefore, mixed-method research designs are used in this study as a procedure for collecting, analyzing, and "combining" quantitative and qualitative methods to understand the research problem (Creswell, 2012: 535). Quantitative data collection instrument is a questionnaire, a questionnaire of needs analysis containing 81 statement items and a questionnaire of feasibility analysis of teaching materials that are being used for 31 items. Both of these instruments apply Likert scale with 5 choices of answers. This is as proposed by Sedarmayanti and Hidayat (2011: 95) and Sugiyono (2015: 93). Qualitative data is obtained from open questions about the experiences of students and lecturers in reading learning in the same questionnaire, as well as content analysis on teaching materials that are being used.

Research respondents are students of semesters 2 and 4 who are and who have been following Basics Reading subjects amounted to 36 people. Meanwhile, 2 lecturers are involved as respondents who have been teaching the Basics Reading subject. The research data was taken in March 2016 at the Department of Indonesian Language Education and Literature, Universitas Negeri Gorontalo.

\section{RESULTS AND DISCUSSION}

\section{Needs Analysis}

Identification The need for writing a reading material refers to three aspects of need, namely necessity, deficiency, and need. These three aspects can illustrate what the students and lecturers need in the development of teaching materials in reading subjects.

\section{Necessity}

It has become an obligation for lecturers to prepare teaching materials so that students have reference material as a handle in the lecture process. Writing and development of many teaching materials into consideration, one of which is a reading strategy that must be mastered by students after following the reading course. Reading strategy works to make it easier for readers to understand reading. Brown (2007:366-371) proposes ten reading comprehension strategies, namely (1) identifying the purpose of reading, (2) using graffiti rules and patterns in reading comprehension; (3) using efficient silent reading (in the heart) to improve fluency, (5) scan text for specific information, (6) use mapping or grouping, (7) guess meaning when unsure, (8) analyze vocabulary, (9) distinguish between literal and Implied meanings, and (10) utilizing discourse markers to process relationships. Meanwhile, Zimmermann and Hutchins (in Judi, 
2007:11) delivered seven strategies in reading, namely: (1) activating or building a background of knowledge; (2) using sensory images; (3) questions; (4) make predictions and conclusions; (5) determine the main idea; (6) using repair options; And (7) synthesis. The strategy that has been proposed by Brown, Zimmermann and Hutchins should be accommodated in the teaching materials.

Related to the above reading strategy, the researcher conducted a study on the syllabus of Basic Reading Course and Reading Development course in Indonesian Language and Literature Education Study Program, State University of Gorontalo. The results show that the reading comprehension strategy has not been all accommodated in the existing lecture syllabus. The important things that have not been clearly defined in the course syllabus are to synthesize information from the text, determine the main idea, activate the knowledge possessed on the topic of the text, and make predictions and conclusions. For that, will be re-arrangement of lecture materials so as to accommodate the strategy of reading comprehension that has been expressed expert.

\section{Lacks}

Referring to the description of the aspect above, it can be seen that the formulation of lecture competency has not been done concretely and in detail. This of course affects the students in understanding the learning materials and the skills to understand the reading material. The syllabus of the lectures analyzed identified the following: (i) the reading comprehension strategy in terms of training and tasks was minimal; (Ii) the emphasis of teaching material on more theories, not yet matched by examples of training texts for reading meaning; (Iii) existing teaching materials have not been based on the needs of the students, but referring to the package books on the market, even then the amount is still very limited.

The shortcomings contained in the reading material should be completed and refined to provide the ideal learning materials for students. Teaching materials developed based on the needs of students will be a very valuable and meaningful material. Likewise with the availability of examples of reading texts, it helps students in formulating meaning through the process of thought and understanding it develops. Therefore, in the development of this teaching material will be considered the presentation of examples of text reading with attention to the type and topic of the text that varies. Through this effort it is expected that students' understanding when reading will get better, so they can understand every kind of information read.

\section{Needs}

Aspects of the need in the development of this resource is inseparable from the results of the analysis of necessities (necessities) and lacks (lacks) on the previous teaching materials. There are seven 7 aspects that are part of the writing and development of teaching materials, namely: the type of information (material) required, the strategy of reading, the type of text, the genre of text, the topic of text, learning activities, and evaluation of learning. Seven aspects were de- veloped into 81 questions, which researchers design through a questionnaire to ask responses (assessments) of students and lecturers who become respondents research. Students who made the respondents ie college students who are and who have followed the lecture courses Basics Reading, amounting to 36 people. Meanwhile, lecturers as respondents amounted to 2 people who have been able to read the Basics of Reading. The following is presented responses of students and lecturers to the questions/statements submitted in the questionnaire.

(a) Information Type

The type of information proposed in this questionnaire is an overview of instructional material material developed in this study. There are 11 points related to the type of information required, the results of the assessment of students and lecturers are summarized in table 1 below. Table 1 above shows the average score of 4.61 students and 4.77 lecturers, both of which are in the most needed category. Thus eleven point information is indispensable in the development of teaching materials. Therefore, the arrangement of the presentation of the material will be adjusted with the analysis of the syllabus items that consider the order of competence to be mastered by the students.

(b) Strategy of reading

Reading strategy is very important in the lecture process, because it can assist students in improving the process of thinking and understanding to get the meaning of reading. For lecturers the strategy will facilitate their work in managing the learning so that it can run effectively. There are 18 items related to the reading strategy, student responses and lecturers summarized in table 2 below.

Table 2 above shows that both students and lecturers want the reading strategy to be applied in teaching materials. Students assessed 15 points in the very high demand category category, and 3 statements had a high demand level, with a total average score of 4.42 . While the lecturer gives an assessment that all reading strategies offered are needed with the average 4.64. Thus, the reading strategy is needed in the development of reading material. For lecturers will facilitate the selection of strategies applied in the learning process, on the other hand this strategy will increase students' understanding of reading material.

The strategy determines the achievement of the learning objectives according to the method chosen and applied by the teacher. Although the method used can not solve the problem of reading comprehension learning faced by the students completely. This is in accordance with the findings of Feng and Chen (2016: 1179) there is no single teaching method that can solve every problem once and for all 'No one teaching method can settle every problem once and for all'.

(c) Type of text

The students' responses which also provide an overview of their need for text types in teaching materials against the 9 types of texts are summarized in table 3 below. 
Table 1. Type of Information required

\begin{tabular}{lcc}
\hline Type of information required & \multicolumn{2}{c}{ Assessment } \\
\cline { 2 - 3 } & Students & Lecturer \\
\hline Explanation of the nature of reading, understanding, and reading comprehension & 4.75 & 5 \\
An explanation of the factors that influence reading comprehension & 4.78 & 5 \\
Explanation of reading comprehension strategy & 4.86 & 4.50 \\
An explanation of the types of knowledge that affect meaning & 4.39 & 4 \\
Explanation of the assessment of reading comprehension & 4.64 & 5 \\
Explanation of quick and effective reading & 4.64 & 5 \\
An explanation of intensive and extensive reading & 4.50 & 5 \\
Explanation of skimming and scanning & 4.39 & 4.5 \\
Explanation of the technique of klose in reading & 4.69 & 5 \\
Explanation of SQ3R reading technique & 4.53 & 5 \\
Explanation of reading model based on thinking pattern & 4.61 & 4.5 \\
Average values & & 4.77 \\
\hline
\end{tabular}

Table 2. Strategy of reading

\begin{tabular}{|c|c|c|}
\hline \multirow[t]{2}{*}{ Strategy of reading } & \multicolumn{2}{|c|}{ Assessment } \\
\hline & Students & Lecturer \\
\hline Determining the purpose of reading & 4.61 & 4.5 \\
\hline Asking questions about the text & 4.44 & 4.5 \\
\hline Identify text structure & 4.39 & 4.5 \\
\hline Identify the word/key phrase in the text & 4.47 & 4.5 \\
\hline Predict the content of the text to be read & 4.28 & 5 \\
\hline Find topics, key ideas, and support ideas in each paragraph & 4.64 & 5 \\
\hline Find answers to the questions asked beforehand & 4.39 & 4.5 \\
\hline Guessing the meaning of a word or phrase by context & 4.19 & 4.5 \\
\hline Utilizing discourse markers to understand text & 4.31 & 4.5 \\
\hline Paraphrase a sentence or paragraph in the text & 4.33 & 4.5 \\
\hline Make inferences to understand the information implicit in the text & 4.64 & 4.5 \\
\hline Make connections to enable the knowledge/experience they have about text & 4.47 & 4.5 \\
\hline Summarizes information from the text & 4.17 & 5 \\
\hline Ignoring information from text & 4.39 & 5 \\
\hline Conclude what has been learned from the text & 4.69 & 4.5 \\
\hline Compare what is learned from the text with prior knowledge/experience & 4.44 & 4.5 \\
\hline Apply information learned from text in the task & 4.56 & 5 \\
\hline Give criticism of the content of the text or the author's opinion & 4.06 & 4.5 \\
\hline Average values & 4.42 & 4.64 \\
\hline
\end{tabular}

Table 3 above shows that the type of text offered to students and faculty is almost entirely at a very high level of need. Students assess the type of text humor is at a high level of need. Lecturers provide an assessment that the types of informative, procedural, and humor texts are at a high level of need. The average score between students and lecturers is almost equal, ie 4.57 for student assessment and 4.56 for lecturer appraisal. Thus, the developed teaching materials contain varied types of texts, as they can help students have the knowledge and experience of reading various types of texts. Even Asl and Mahmoudi (2017: 341) have proven that texts, especially elaborative texts, have a statistically significant influence on the reading comprehension of learners. Therefore, the selection of text types in the development of reading material is very influential on students' reading comprehension.

(d) Genre of text

The text genres offered to students and lecturers are seven varieties with responses as summarized in table 4 below.

Table 4 shows that the seven genres of text offered to students and lecturers have a high and high demand response. Newspaper text genres, hints, ads and invites 
Table 3. Type of text

\begin{tabular}{lcc}
\hline Type of text & \multicolumn{2}{c}{ Assessment } \\
\cline { 2 - 3 } & Students & Lecturer \\
\hline Description text & 4.81 & 5 \\
Narrative text & 4.69 & 5 \\
Exposition text & 4.58 & 5 \\
Persuasive text & 4.56 & 5 \\
Informative text & 4.83 & 4 \\
Procedural text & 4.53 & 4 \\
Conversation text & 4.28 & 4.5 \\
Humor text & 4.17 & 4 \\
Text of journalism & 4.67 & 4.5 \\
Average values & 4.57 & 4.56 \\
\hline
\end{tabular}

Table 4. Genre of text

\begin{tabular}{lll}
\hline Genre of text & Assessment & \\
\cline { 2 - 3 } & Students & Lecturer \\
\hline Academic essay & 4.72 & 4.5 \\
Biography & 4.36 & 5 \\
Review the book & 4.69 & 5 \\
Newspaper & 4.19 & 5 \\
Hints & 4.64 & 4 \\
Advertisement & 3.97 & 4 \\
Invitation & 4.00 & 4 \\
Average values & 4.37 & 4.50 \\
\hline
\end{tabular}

Table 5. Topic of text

\begin{tabular}{lcc}
\hline Topic of text & \multicolumn{2}{c}{ Assessment } \\
\cline { 2 - 3 } & Students & Lecturer \\
\hline Science and technology & 4.89 & 4.5 \\
Social & 4.78 & 4.5 \\
Culture & 4.89 & 5 \\
Important phenomenon & 4.47 & 4.5 \\
Education & 4.97 & 4.5 \\
Natural phenomena & 4.19 & 4.5 \\
Natural disasters & 4.03 & 4.5 \\
Sports & 3.89 & 4 \\
Health & 4.50 & 4.5 \\
Language & 4.94 & 5 \\
Literature & 4.94 & 5 \\
Moral & 4.78 & 5 \\
Plant & 3.72 & 4 \\
Animal & 3.75 & 4 \\
Average values & 4.48 & 4.54 \\
\hline
\end{tabular}

are at a high level of need. The average of student assessment is 4.37 , and the mean of lecturer appraisal is 4.5. This means that no text genre is at a sufficiently high, low, and very low level of need. Referring to the results of the students 'and lecturers' responses to the text genre, it can be concluded that reading material needs to include various genres of text, especially academic essay genres, book reviews, manuals, biographies, newspapers, invitations, and advertisements. Thus, this teaching material will help students can have knowledge and experience to read with various genres of text contained in it.

(e) Topic of text

There are 14 types of text topics offered to students and lecturers through questionnaires have obtained their responses as summarized in table 5 below.

Table 5 shows that from the fourteen topics offered, there are nine topics at very high demand, while the five topics of natural phenomena, natural disasters, sports, plants and animals are at a high level of need. The average assessment of students 4.48 and lecturers 4.54, this means not much difference will be the need of text topics in teaching materials. While reading material has included a number of diverse text topics, it will greatly assist students in improving their knowledge and experience of reading text on various topics. Thus, topical texts on education, language, literature, science, science, culture, social, morals, health, important events will take precedence in the selection of reading texts as student training materials. The importance of the topic has been proved by Mahmoudi \& Mahmoudi (2017: 503) has found a significant effect for the topic of familiarity that would be helpful to readers at all levels.

(f) Learning Activities

To find out the needs of students and lecturers related to reading learning activities, researchers formulate 19 statements in the questionnaire. The student and lecturer responses are summarized in table 6 below.

Table 6 shows that the 19 learning activities that will be developed in teaching materials, have a very high demand respom. This is seen from the average score of 4.51 students and 4.74 lecturers, both of which are at very high levels. Thus, the teaching materials to read need to include all types of learning activities mentioned above, especially considering everything is at the level of needs is very high and high. When students are accustomed to a variety of varied learning activities, it will provide a meaningful learning experience.

(g) Evaluation of Learning

Evaluation of learning is one aspect that must be considered in the learning process. The needs of students and lecturers on the evaluation of learning are revealed through 3 point statement. The results of student and lecturer responses to the evaluation of learning are summarized in table 7 below.

Table 7 above shows that 3 types of learning evaluations are at very high demand levels. Thus, reading materials should include evaluation of each learning unit, learning center (UTS), and at the end of the learning program (UAS). Evaluation is very important and needs to be done as a reflection of the learning process that has been done. This is in accordance with the findings of Alkhaldi (2010: 296), the process of materials evaluation. 
Table 6. Learning activities

\begin{tabular}{lcc}
\hline Learning activities & \multicolumn{2}{c}{ Assessment } \\
\cline { 2 - 3 } & Students & Lecturer \\
\hline Asking questions about the text & 4.69 & 5 \\
$\begin{array}{l}\text { Find answers to the questions asked } \\
\text { about the text }\end{array}$ & 4.75 & 5 \\
$\begin{array}{l}\text { Predict the text content } \\
\text { Linking knowledge/experience } \\
\text { possessed with information on text }\end{array}$ & 4.42 & 4.5 \\
$\begin{array}{l}\text { Identify text structure } \\
\text { Utilizing discourse markers to }\end{array}$ & 4.64 & 5 \\
understand text & 4.44 & 4.5 \\
$\begin{array}{l}\text { Identify the word/key phrase in the } \\
\text { text }\end{array}$ & 4.58 & 4.5 \\
$\begin{array}{l}\text { Find topics, main ideas, and support } \\
\text { ideas }\end{array}$ & 4.75 & 5 \\
$\begin{array}{l}\text { Guessing the meaning of a word or } \\
\text { phrase by context }\end{array}$ & 4.33 & 5 \\
$\begin{array}{l}\text { Paraphrase a sentence or paragraph } \\
\text { in the text }\end{array}$ & 4.47 & 5 \\
$\begin{array}{l}\text { Summarizes information from the } \\
\text { text }\end{array}$ & 4.50 & 5 \\
$\begin{array}{l}\text { Synthesizes information from text } \\
\text { Summing up information from text } \\
\text { Criticize the author's opinion on the } \\
\text { author's text }\end{array}$ & 4.50 & 5 \\
$\begin{array}{l}\text { Develop vocabulary related to text } \\
\text { Listening to what the speaker is }\end{array}$ & 4.50 & 5 \\
saying & 4.53 & 5 \\
$\begin{array}{l}\text { Write down what has been learned } \\
\text { from the text }\end{array}$ & 4.47 & 5 \\
$\begin{array}{l}\text { Discuss what has been learned from } \\
\text { the text }\end{array}$ & 4.53 \\
Present what has been learned & 4.39 & 5 \\
Average values & 4.51 & 5 \\
\hline
\end{tabular}

Table 7. Evaluation of learning

\begin{tabular}{lcc}
\hline Evaluation of learning & \multicolumn{2}{c}{ Assessment } \\
\cline { 2 - 3 } & Students & Lecturer \\
\hline $\begin{array}{l}\text { The test or evaluation at the end of } \\
\text { each learning unit (formative test) }\end{array}$ & 4.67 & 5 \\
$\begin{array}{l}\text { Test in the middle of the learning } \\
\text { program (midterm exam) }\end{array}$ & 4.75 & 5 \\
$\begin{array}{l}\text { The test at the end of the learning } \\
\text { program (final exam semester) } \\
\text { Average values }\end{array}$ & 4.92 & 5 \\
\hline
\end{tabular}

\section{Feasibility Analysis of Teaching Materials}

Feasibility analysis of teaching materials is done on the reading material that is used today. Situation analysis is an analysis of the reading material used today. This analysis is done through two stages, first through a questionnaire in which contains a number of questions related to the current state of the teaching materials. The questionnaire was distributed to the students of Indonesian Language and Literature Department and lecturer in reading subject. Second, the researcher identifies directly related to the teaching materials that are being used. In this section, the researcher conducts content analysis on reading teaching material that is being used.

Through the questionnaire, the researchers analyzed the feasibility of reading reading materials by distributing questionnaires to students who are and who have followed the Basic Reading Course of 36 people, as well as two lecturers who teach the Basics of Reading. The feasibility of teaching materials is seen from five aspects, namely (1) the content of the teaching materials of 16 questions, (2) the teaching material organization of 3 questions, (3) the use of language in teaching materials with 5 questions, (4), And (5) completeness of teaching material support by 1 question. Thus, there are 31 questions that are asked to students and lecturers to know the feasibility of teaching materials that are being used today.

a) Contents of Teaching Materials

The feasibility of the content of the reading material currently in use refers to the 16 items of questions raised, with the results of the assessment of students and lecturers as described in table 8 below.

Table 8 above shows that the content of the reading material being used is currently in a fairly high category. Based on the assessment of students and lecturers, it is known that reading material that is temporarily used is not maximized to improve student understanding. This is related to the unbalanced presentation of material between theory and reading examples. The reading courses include practical courses, so it takes the presentation of sample readings that cover the various types and topics of the text. But it has not been fulfilled in reading material that is temporarily used during lectures.

b) Organization of Teaching Materials

The feasibility of reading material reading organizations which are temporarily used is seen in three aspects, with the results of the assessment of students and lecturers listed in table 9 below.

Table 9 shows if the teaching teaching material organization that is being used is on a high enough feasibility with a mean score of 3.06. Organizational arrangement of teaching materials also influences students' understanding. This is a concern in developing teaching materials so as to have a very high feasibility.

c) Use of Language in Teaching Materials

The feasibility of reading reading material that is being used in terms of language use is revealed through 5 questions. The results of the assessment of students and lecturers are summarized in table 10 below.

Table 10 above is seen when the average student assessment of 3.38 and lecturers is 3.10 , both of which are at a high enough level of feasibility. This indicates that the language use aspect of the reading material that is being used still has weaknesses. These results become the reference of researchers in developing teaching materials to read so that from the aspect of language has a very 
Table 8. Contents of teaching materials

\begin{tabular}{lcc}
\hline Item statement & \multicolumn{1}{c}{ Assessment } \\
\cline { 2 - 3 } & Students & Lecturer \\
\hline Learning materials are in accordance with the purpose of learning & 3.06 & 3.92 \\
Learning materials are in accordance with the needs of students & 2.94 & 3 \\
Learning materials are in accordance with the level of student needs & 2.50 & 3 \\
The examples given are easy to understand & 2.22 & 2.69 \\
The presentation of the material is balanced between the theory and examples of bacan texts & 2.33 & 2.5 \\
Grammatical features in the text are clearly exposed & 2.53 \\
The type of text used has varied & 3.06 \\
The text topics used vary & 3.28 \\
Study instructions are clear & 3.33 \\
Learning activities are associated with the development of listening skills & 3.25 \\
Learning activities are associated with the development of speaking skills & 3.03 \\
Learning activities are associated with the development of writing skills & 3.28 \\
Exercise or assignment is varied & 3.5 \\
Exercises or assignments allow students to work together in groups & 3.33 \\
Exercises or assignments allow students to study independently & 3.19 \\
Evaluation of the learning given vary & 2.93 \\
Average values & 3
\end{tabular}

Table 9. Organization of teaching materials

\begin{tabular}{lcc}
\hline Item statement & \multicolumn{2}{c}{ Assessment } \\
\cline { 2 - 3 } & Students & Lecturer \\
\hline $\begin{array}{l}\text { Sorting material based on text } \\
\text { difficulty level is correct }\end{array}$ & 3.11 & 3 \\
$\begin{array}{l}\text { Sorting of materials based on the } \\
\text { difficulty level of reading strategy is } \\
\text { appropriate }\end{array}$ & 3.14 & 3 \\
$\begin{array}{l}\text { Loading the material between } \\
\text { the learning units in the teaching } \\
\text { materials is balanced }\end{array}$ & 2.94 & 3 \\
Average values & & \\
\hline
\end{tabular}

Table 10. Use of language in teaching materials

\begin{tabular}{lcc}
\hline Item statement & \multicolumn{2}{c}{ Assessment } \\
\cline { 2 - 3 } & Students & Lecturer \\
\hline The use of grammar is correct & 3.44 & 3 \\
The use of punctuation is correct & 3.61 & 3 \\
The use of words is correct & 3.42 & 3.5 \\
The use of transition markers is & 3.14 & 3 \\
correct & & \\
Spelling is correct & 3.31 & 3 \\
Average values & 3.38 & 3.10 \\
\hline
\end{tabular}

high level of feasibility. Well-organized language, will help students understand the material optimally.

d) Layout of Teaching Materials

The feasibility of reading material is seen from 6 points of assessment aspect. Assessment of students and lecturers is summarized in table 11 below.
Table 11. Layout of teaching materials

\begin{tabular}{lcc}
\hline Item statement & \multicolumn{2}{c}{ Assessment } \\
\cline { 2 - 3 } & Students & Lecturer \\
\hline $\begin{array}{l}\text { The presentation of tables, graphs, } \\
\text { diagrams is correct }\end{array}$ & 3.11 & 3.5 \\
Preparation of paragraphs is correct & 3.53 & 3 \\
The use of fonts is correct & 3.69 & 3.5 \\
The use of font size is correct & 3.53 & 3.5 \\
The visuals that accompany the & 3.08 & 2.5 \\
text are correct & & \\
The quality of printed teaching & 3.11 & 3.5 \\
materials is good & & \\
Average values & 3.34 & 3.25 \\
\hline
\end{tabular}

Table 12. Supporting material support materials

\begin{tabular}{lcc}
\hline Item statement & \multicolumn{2}{c}{ Assessment } \\
\cline { 2 - 3 } & Students & Lecturer \\
\hline $\begin{array}{l}\text { The instruction manual is clearly } \\
\text { written }\end{array}$ & 3.36 & 3 \\
Average values & 3.36 & 3 \\
\hline
\end{tabular}

Table 11 shows if the subject of reading reading material is at a fairly high level of feasibility with a mean score of 3.34. It's very good to be improved in the development of teaching materials, so it's even better the aspect of the layout.

e) Supporting Material Support Materials

The feasibility of the completeness of supporting the reading material has obtained the assessment result from the students as summarized in table 12 below. 
Table 12 above shows that the completeness of the teaching material support currently in use from the aspect of the instruction manual is at a sufficiently high level of eligibility. It still needs to be improved so that the developed teaching material becomes very high from the presentation aspect of the material use manual.

Referring to the assessment of students and lecturers, the results obtained 4 items (12.90\%) low category, 22 items $(70.97 \%)$ enough category, and 5 items $(16.13 \%)$ high category, so there is no point of assessment that categorized very high. Thus, it is generally at a fairly high level of eligibility. This is in line with the analysis of the content that researchers do obtained the fact that the teaching materials used now not in accordance with the needs of students, especially in the following things.

a) There is no explanation on the nature of understanding and reading comprehension

b) Not yet explaining the factors that affect reading comprehension

c) Not yet contains explanation of reading comprehension strategy

d) Not yet explaining the types of knowledge that affect reading comprehension

e) The type of text presented has not varied

f) The text genres presented have not varied

g) The topic of the presented text has not varied

h) Does not contain any sample reading required by the students

i) Has not presented a learning evaluation at each end of the learning unit in teaching materials.

These points are a major concern in the development of materials so as to produce a more complete teaching material than before. The teaching materials organization aspect will also remain the focus of improvement. The same will be done in the improvement and development of aspects of language and subject matter teaching.

\section{CONCLUSION}

Needs analysis and feasibility analysis of the material being used is very important to be done in the development of teaching materials reading as a lecture subject reading for students. Needs analysis and situation analysis is very important to be done to write and develop teaching materials to read for the interest of reading lecture for students. The need for teaching material development is seen from 7 aspects, namely reading material information, reading strategy, text type, text genre, text topic, learning activity, and evaluation of learning, total question/statement 81 item. As a result, students and lecturers assessed 63 items (77.78\%) were in the most needed category, and 18 (22.22\%) with the required category. This means that a statement item with a much needed category will take precedence in the development of teaching materials, while the category 'needed' will be a consideration.

The analysis of teaching materials currently being used is analyzed from the content of teaching materials, teach- ing material organization, language, perwajahan, and teaching material supporting materials, as many as 31 items of questions. Situation analysis of the current teaching materials is reviewed from the aspect of the content of teaching materials, teaching material organization, language, layout, and completeness of teaching material support, as many as 31 questions. The results obtained 4 items (12.90\%) low category, 22 items (70.97\%) enough category, and 5 items $(16.13 \%)$ high category. Teaching materials that are being used now still lack the aspects of the content, text type, text genre, test topics, and evaluation of each learning unit.

\section{REFERENCES}

Alkhaldi A.A. (2010). Developing a Principled Framework for Materials Evaluation: Some Considerations. Advances in Language and Literary Studies, Vol. 1 (2), 281-298. http://doi:10.7575/aiac.alls.v.1n.2p.281

Asl, S.E. \& Mahmoudi, A. (2017). Effect of Elaborative Text Modification on Preintermediate Male and Female EFL Learners' Reading Comprehension. Journal of Language Teaching and Research, Vol. 8 (2), 337-342. http://dx.doi.org/10.17507/jltr.0802.16

Brown, H.D. (2007). Prinsip Pembelajaran dan Pengajaran Bahasa. Jakarta: Kedutaan Besar Amerika Serikat, Pearson Education.

Creswell, J.W. (2012). Educational Research: Planning, Conducting, and Evaluatif Quantitative and Qualitative Research. Boston: Pearson

Feng. Q. \& Chen. L. (2016). A Study on Teaching Methodes of Reading Comprehensions Strategies by Comparison betwen TEM-4 Reading Comprehension and IELTS Academic Comprehension Reading. Journal of Language Teaching and Research, Vol. 7 (6), 1174-1180. http:// dx.doi.org/10.17507/jltr.0706.15

Gay, L.R., Milss, G. E. \& Airasian, P.W. (2012). Educational Research: Competencies for Analysis and Applications Tenth Edition. USA: Pearson.

Graves, K. (2000). Designing Language Course: A Guide for Teachers. Boston: Heinle and Heinle Thomson Learning.

Grellet, F. (1981). Developing Reading Skills: A practical guide to reading comprehension exercises. London: Cambridge University Press.

Judi, M. (2007). Collaborative Strategies for Teaching Reading Comprehension: Maximizing Your Imfact. Chicago: American Library Association.

Mahmoudi, S. \& Mahmoudi, A. (2017). Can Topic Familiarity Override Language Proficiency in Reading Comprehension. Journal of Language Teaching and Research, Vol. 8 (3), 496-506. http://dx.doi.org/10.17507/ jltr.0803.07

Nation, I.S.P \& Macalister, J. (2010). Language Curriculum Design. New York: Routledge.

Nunan, D. (1996). The Learner-Centered Curriculum. Cambridge: Cambridge University Press.

Richards, J.C. (2001). Curriculum Development in Language Teaching. Cambridge: Cambridge University Press. 
Sedarmayanti \& Hidayat, S. (2011). Metodologi Penelitian. Tomlinson, Brian. (2007). Developing Materials for LanBandung: CV. Mandar Maju. guage Teaching. London: Cromwel Press

Sugiyono. (2015). Metode Penelitian \& Pengembangan: Research and Development. Bandung: Alfabeta.

Suparman, M.A. (2004). Desain Instructional. Jakarta: Universitas Terbuka.

Verspoor, M.H., de Boot, K., \& Lowie, W. (2011). A Dynamic Approach to Second Language Development: Methods and Thecniques. Amsterdam/Philadhepia: John Benjamins Publishing Company. 